\title{
Damage Potential and Loss Caused By the Groundnut Bruchid Caryedon Serratus Olivier [Coleoptera: Bruchidae) On Stored Groundnut and Tamarind in Yola
}

\author{
${ }^{1}$ Oaya, C.S., ${ }^{2}$ Malgwi, A. M. And ${ }^{3}$ Samaila, A. E. \\ ${ }^{I}$ Department of Agricultural Technology Adamawa State College of Agriculutre, P. M. B. 2088, Ganye, \\ Adamawa State. \\ ${ }^{2}$ Department of Crop Protection Federal University of Technology P. M. B. 2076, Yola Adamawa State
}

\begin{abstract}
The Damage Potential, Loss and Physical Damage done to shelled, unshelled ground nut and tamarind by the groundnut bruchid were evaluated. The experiment was carried out in the Laboratory of the Department of Crop Production and Horticulture, Federal University of Technology, Yola, at room temperature $38-39^{\circ} \mathrm{C}$ and relative humidity $45-50^{\circ} \mathrm{C}$. It was arranged in a Completely Randomized Design (CRD). The results obtained showed that the groundnut bruchid Caryedon serratus has the Potential and ability to destroy stored groundnuts and tamarind, making it unfit for consumption. Up to $90 \%, 80 \%$ and $79 \%$ damage and $70 \%$, $68 \%$ and $64 \%$ weight loss were recorded in shelled, unshelled groundnut and tamarind respectively. All the treatments had high significant damage and loss caused by the test insect compared to the controls at $P \leq 0.05$ level of significance using the Student Newman-Keuls (SNK) test for variables. Percentage mortality of adult bruchid was highest in unshelled groundnut (46.27) compared to tamarind (44.1) and females lay upto 305 eggs on shelled groundnut than unshelled groundnut (280.0) and tamarind (283.3).
\end{abstract}

Key Words: Damage, Bruchid, Pest, Mortality, Control, Groundnut, Tamarind.

\section{Introduction}

Groundnut (Arachis hypogea L.) also known as peanut earthnut, gobbers, pinders, etc belongs to the family leguminosae (Fabacea) (Beghnin and Sewadah, 2003). Other members of this family include cowpea, soyabeans, tamarind, melon etc (Ashley, 1993). Groundnut originated from South America (Brazil) and was introduced into Nigeria by the Portuguese after the $16^{\text {th }}$ century (Adeyemi, 1968). Groundnut production in Africa has been estimated at 4.6 metric tons, with Nigeria, being the major producers in Africa (Ashley, 1993). According to Nyilra, (1988), Nigerian's production of unshelled nut is about 2.6 metric tones annually from a land area of approximately 2.5 million hectares. Groundnut thrives best on a well-drained sandy-loam soil, this type of soil facilitates easy penetration of pegs and their development, hence their harvesting (Yayock, 1984). Weiss (2000), suggested that, temperature range of $25-300 \mathrm{C}$, rainfall of $500-1000 \mathrm{~mm}$ and a PH range of 6.0-6.5 is considered optimum for groundnut production. Groundnut is a major cash crop which serves as a foreign exchange earner prior to the petroleum boom in Nigeria (Adeyemi, 1968). According to Aribisala (1993), the crop is a good source of protein, fats and oil, vitamins etc. Shellled groundnuts are fried, roasted and salted which is eaten as snacks. The crop serves as raw materials for some food industries and also as feed concentrated for livestock (David and Adamu, 1988).

Tamarind (Tamarindus indica L.), from the Arabic word tamar is a tree in the family Fabacea (Hooker, 1991). It is a tropical tree, native to tropical Africa (Dalton, 1991). It was introduced into India and it was from there that it reached the Persian, Arabs, the ancient Egyptians and the Greeks in the $4^{\text {th }}$ century B.C. (Fosberg, 1993). Mexico has over 10,000 acres (4440 ha) of tamarind trees. There are commercial tamarind plantations also in Brazil, India and in Cenetral America (Malton, 1987). He further stressed that, in India, the tamarind seeds are processed into powder used for sizing and finishing cotton and Jute which is certified as $30 \%$ efficient and more economical than the cornstarch (Dalton, 1991). In Africa, tamarind has the potential to improve the nutrition status of the people, boost food security and support sustainable land care (Fosberg, 1993). In Nigeria, the seeds are processed and made into 'dawa-dawa' and stages and in store, though the extent of insect damage varies from one agro-ecological zone to the other (Hooker, 1991). In northern Nigeria alone, yield loss of ground nut due to Caryedon serratus infestation is estimated at 150,000 - 250,000 tones annually, about 35\% loss resulting to several million naira loss to the country (IIT A, 2000). No exact figure has been presented as accurate interms of the degree of infestation of Caryedon serratus in stored tamarind. However, tamarind in storage is destroyed beyond measure by the same Caryedon serratus given optimum favourable conditions (IIT A, 2000).

The extent of post harvest losses has prompted several studies of insects pests population development on groundnut and tamarind in store. However, few or no attempts have been made to measure the degree of losses caused by these insects (Caryedon sorratus) either in farmers store or in a large scale commercial storage 
in Nigeria. Consequently, there is inadequate information on appropriate methods for assessing post-harvest losses especially for tamarind which share the same storage pest with groundnut. Therefore, it is imperative to look at the damage potential and the loss caused by this insect pest (Caryedon serratus) on stored groundnut and tamarind, which are important economic crops.

\section{Materials and Method.}

The experiment was carried out in the Laboratory of the Department of Crop Production and Horticulture, Federal University of Technology, Yola in 2008 and 2009. The University is located in Sangere village, Girei Local Government area, within longitude $9^{\circ} 14^{\prime \prime}$ North and latitude $12^{\circ} 13^{\prime \prime}$ East of the equator in the Northern Guinea Savannah agroecological zone of Nigeria (Adebayo, 1999). This was aimed at determining the damage potential and loss caused by the groundnut bruchid Caryedon serratus (Olivier) in stored groundnuts and tamarind. The tamarind was depodded or unshelled as farmers used to store them. Ten pairs of clean freshly emerged adult Caryedon serratus were introduced into containers already containing 100 grams of the stored products (groundnut and tamarind) with no control measures used. The initial weight of the stored products were taken and the moisture content of the seeds used was $11-12 \%$. There were six (6) treatments replicated three (3) times arranged on the table in the Laboratory at a room temperature of $38-39^{\circ} \mathrm{C}$ and relative humidity of 40-45\%. The experimental design used was the Completely Randomized Design (CRD) for a period of six (6) months from January to June in 2009 and 2010. The time was chosen because, that is the critical stage groundnuts and tamarind are usually stored after harvest. Dead bruchids were removed at the experiment and the results taken.

The groundnut both shelled and unshelled used were the local variety found in the study area popularly known as the 'kampalla" and it was obtained locally from the farmers in the village. The tamarind used was bought from the farmers in the market just at harvest. They were sorted out to remove injured or infested ones with pests. The adults Caryedon serratus were collected from infested seeds of groundnut and tamarind maintained or cultured in a large stock. The age of the test insects used was standardized by collecting the larvae that were about to emerge within the range of $0-24 \mathrm{hrs}$ old. This gave room for uniform oviposition period and the number of eggs laid thereafter. The containers used were covered with muslin cloth in order to prevent the bruchid from escaping, which is a typical conditions most subsistence farmers store their crops for immediate consumption.

The data collated was analysed using ANOVA and means were separated using Student-Neuman Keuls (SNK) test for variables.

The results obtained were calculated using similar formula by Lale (2002) AS follows:

(i) Percentage (\%) loss $=\underline{\mathrm{a}-\mathrm{b}} \times 100$

A

Where:

$\mathrm{a} \quad=$ initial weight of stored produce before starting experiment $\mid$

$\mathrm{b} \quad=$ Final weight of stored produce after terminating experiment

(ii) Mortality (\%) = $\quad$ Number of dead bruchid $\times 100$

Total number of live and dead bruchid

(iii) Percentage damaged seeds $=$ Number of damaged seeds $\times 100$

Initial Number of seeds

\section{Results}

The results obtained showed (Table 1) that, shelled groundnut gave the highest mean percentage damage seeds (90.00) followed by unshelled groundnut (80.68); Tamarind (79.67); and the least was recorded in the control with tamarind (34.00) at $\mathrm{P} \leq 0.05$ using the student Newman - Keuls (SNK) test for variables. On the other hand, control with tamarind gave the highest mean percentage undamaged seeds (65.33) followed by control with unshelled groundnut (58.33); control for shelled groundnut (43.00) and the least was observed in shelled groundnut (10.00) at $\mathrm{P} \leq 0.05$ using the Student-Newman Keuls (SNK). The highest mean percentage mortality was obtained in unshelled groundnut (49.47) followed by shelled groundnut (46.27); tamarind (44.10); control with shelled groundnut (10.30) and control with tamarind (9.00) as seen in Table 1 gave the least mean percentage mortality at $\mathrm{P} \leq 0.05$ using the Student Newman-Keuls (SNK) test for variables.

Moreover, Table 2 showed that, shelled groundnut gave the highest mean number of adults alive (21.67) followed by tamarind and unshelled groundnut (17.33 and 16.68) and the least was observed in the control for shelled groundnut $(0.33)$ at $\mathrm{P} \leq 0.05$. In addition, higher mean number of eggs laid was obtained in shelled groundnut (305.67) slightly followed by tamarind and unshelled groundnut (283.33 and 280.00) 
respectively and the least was recorded in the control for tamarind (20.33). In the same vane, the highest mean percentage weight loss in grams was recorded in shelled groundnut and unshelled groundnut (70.33 and 68.33) narrowly followed by tamarind (64.00)., Shear butter (54.33)., Locust bean (52.00) as stated in Table 2 and the least was obtained in the control for tamarind (8.00) at $\mathrm{P} \leq 0.05$ using the Student Newman - Keuls (SNK) test for variables. The difference on the damage is clearly showed in Fig. 1 and fig 2.

Table 1. Mean Percentage (\%) Damage Potential and Loss caused by Caryedon serratus on Stored Groundnut and Tamarind at in 2008 and 2009.

\begin{tabular}{llll}
\hline Treatments & $\begin{array}{l}\text { Mean Damage } \\
\text { Seeds }\end{array}$ & $\begin{array}{l}\text { Percentage } \\
\text { Undamaged } \\
\text { Seeds }\end{array}$ & $\begin{array}{l}\text { Mean } \\
\text { Percentage } \\
\text { Mortality }\end{array}$ \\
\hline Shelled groundnut (AF) & $90.00 \mathrm{a}$ & $10.00 \mathrm{~g}$ & $46.27 \mathrm{~b}$ \\
Unshelled groundnut (AI) & $80.68 \mathrm{~b}$ & $19.33 \mathrm{f}$ & $49.47 \mathrm{~b}$ \\
Tamarind (AF) & $78.68 \mathrm{~b}$ & $20.33 \mathrm{f}$ & $44.10 \mathrm{bc}$ \\
Shear butter & $59.00 \mathrm{~cd}$ & $41.00 \mathrm{e}$ & $54.53 \mathrm{a}$ \\
Locust bean & $61.33 \mathrm{c}$ & $38.67 \mathrm{e}$ & $53.77 \mathrm{a}$ \\
Control for shelled groundnut (NUI) & $57.00 \mathrm{~d}$ & $43.00 \mathrm{~d}$ & $10.30 \mathrm{c}$ \\
Control for unshelled groundnut (NUI) & $41.68 \mathrm{e}$ & $58.33 \mathrm{c}$ & $8.65 \mathrm{~cd}$ \\
Control for tamarind (NUI) & $34.00 \mathrm{f}$ & $65.33 \mathrm{~b}$ & $9.00 \mathrm{c}$ \\
Mean & 56.30 & 43.60 & 28.71 \\
C.V & 2.46 & 3.22 & 82.23 \\
\hline
\end{tabular}

Means followed by the same letter (s) are not significantly different at $\mathrm{P} \leq 0.05$, using the Student Newman - Keuls (SNK) mean separation. AI (Artificially infected in C. serial) NI (Naturally infected as bought from farers).

Table 2. Mean Number of adults alive, eggs laid and percentage weight loss in 2008 and 2009.

\begin{tabular}{llll}
\hline Treatments & $\begin{array}{l}\text { Mean number a of } \\
\text { adults alive }\end{array}$ & $\begin{array}{l}\text { Mean number } \\
\text { of eggs laid }\end{array}$ & $\begin{array}{l}\text { Mean } \\
\text { Percentage } \\
\text { weight loss }\end{array}$ \\
\hline Shelled groundnut (AF) & $21.68 \mathrm{a}$ & $305.68 \mathrm{a}$ & $70.33 \mathrm{a}$ \\
Unshelled groundnut (AI) & $16.68 \mathrm{~b}$ & $280.00 \mathrm{~b}$ & $68.33 \mathrm{a}$ \\
Tamarind (AF) & $17.33 \mathrm{~b}$ & $283.33 \mathrm{~b}$ & $64.00 \mathrm{~b}$ \\
Shear butter & $10.00 \mathrm{c}$ & $189.67 \mathrm{c}$ & $54.33 \mathrm{c}$ \\
Locust bean & $6.33 \mathrm{~d}$ & $168.00 \mathrm{~d}$ & $52.00 \mathrm{c}$ \\
Control for shelled groundnut (NUI) & $0.33 \mathrm{e}$ & $29.33 \mathrm{c}$ & $11.00 \mathrm{~d}$ \\
Control for unshelled groundnut (NUI) & $1.00 \mathrm{e}$ & $22.68 \mathrm{f}$ & $10.00 \mathrm{~d}$ \\
Control for tamarind (NUI) & $1.00 \mathrm{e}$ & $20.33 \mathrm{f}$ & $8.00 \mathrm{~d}$ \\
Mean & 7.47 & 134.53 & 35.50 \\
C.V & 16.89 & 7.3 & 9.52 \\
\hline
\end{tabular}

Means followed by the same letters are not significantly different at $\mathrm{P} \leq 0.05$, using the Student Newman - Keuls (SNK) mean separation. AI (Artificially infected in C. serial) NI (Naturally infected as bought from farers). 

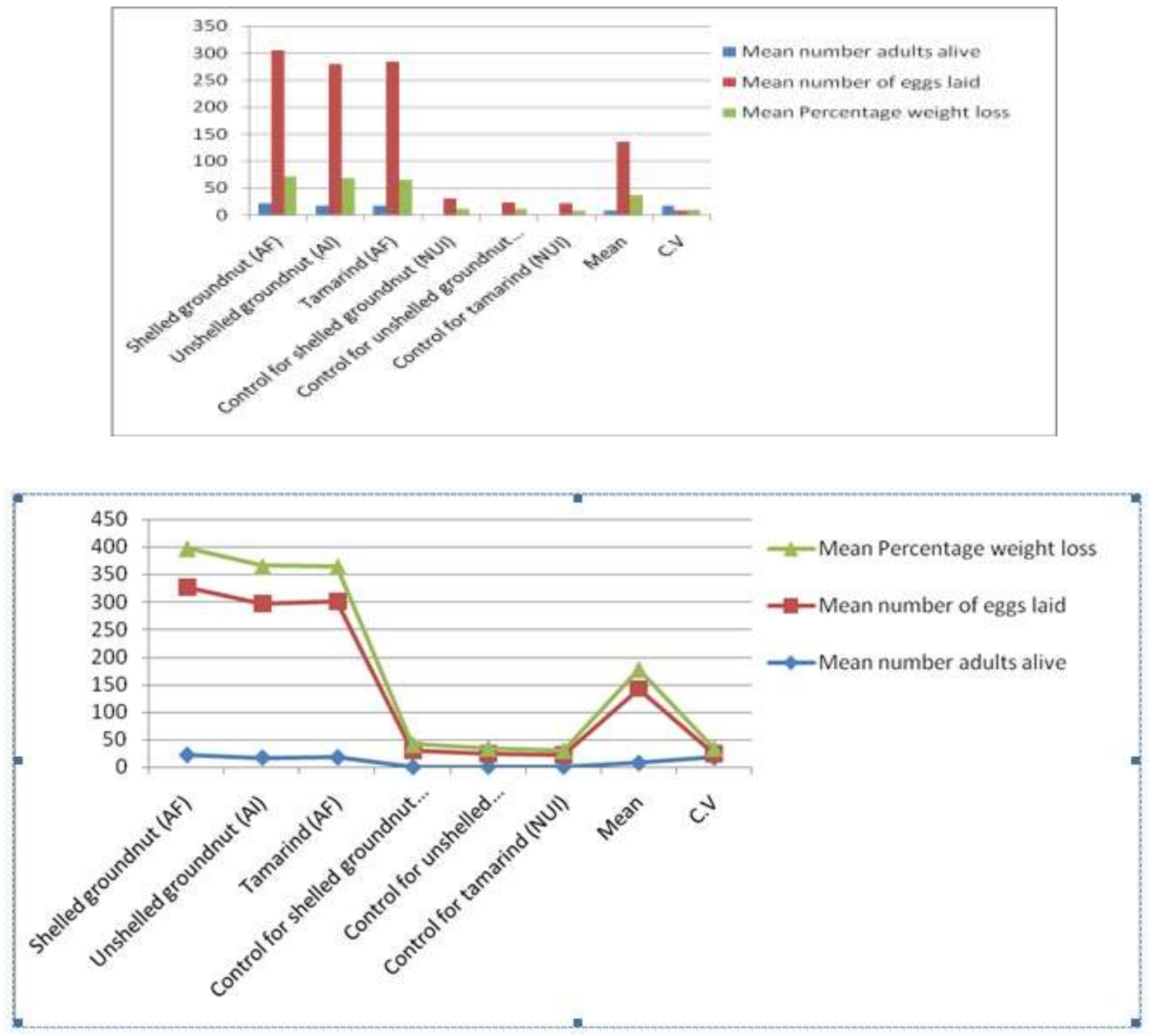

\section{Discussions}

The results obtained showed that, all the stored produce in were relatively susceptible to attack by the seratus in store. This means that, Caryedon serratus has the potential of destroying these stored products making it unfit for consumption. This agrees with Appert, (1987) who reported that, infestation by Caryedon serratus results in damp grain heating, reduction in food calue of the stored product as a result of degradation of the glucids and parotids, musty smell damage to grain, jeopardizing germinability and the development of mycotoxins or poisons such as aflotoxins in groundnut due to fungal metabolism.

For all the stored products, high mean percentage damaged seeds and low mean percentage undamaged seeds were recorded since no control measures were used and this agrees with Morgan (1973) which states that, there could be more $80 \%$ damage of stored products when storage is done without control measures. Moreover, the mean percentage mortality, mean number of adults alive and the mean number of eggs laid on the artificially infested products were significantly high compared to the control inartificially infested provoked. This was because the test insect were introduced into the stored products and there were no protestants to suppress adults emergence and also reduce oviposition or the egg laying ability of the bruchid. Like wise, high mean percentage weight loss were recorded in all the stored products and this agrees with Williams (1980) and Lale (1994) who reported that, infestation of stored products by bruchids could lead to $60-80 \%$ weight loss, rendering it unattractive for consumption.

By man, while, there were high significant difference between the stored products and the control since the control gave high percentage undamaged and low percentage damaged seeds, low percentage weight loss, low number of eggs laid and less number of adults alive. This was because the test insects were not introduced into the stored products. This may be that some of the produce might have been infested on the farm before storage. This is in agreement with Conway (1974) that, the bruchid Caryedon serratus lays its eggs on freshly harvested pods of farm produce that were sun dried before storage. 


\section{CONCLUSION}

It is evident that, the groundnut bruchid Carydon serratus (Olivier) is potentia and a serious insect pest of groundnut, tamarind, shear better and locot been in store as shown by the result $\sim$ obtained. It was found out that, Caryedon serratus (Olivier) can damage both groundnut (shelled) and unshelled) and tamarind in store to an unacceptable state and rendering it unfit for consumption for both humans and livestock when control measures are no applied. According to the results obtained, there was up to $90 \%$ damage more than $60 \%$ weight loss and up to 305 eggs laid in some of the treatments. Therefore the high mean percentage damaged seeds, high mean number of adults alive, high mean number of eggs laid and the high mean percentage weight loss recorded is a confirmation that, this destructive bruchid is a potential insect pest of not only groundnut which much work was to on tree crop produce tamarind, locust been and shear butter which are economic tree crops that is useful to man such produce should not be stored together since they shear the same pest. Records on damage potential of tarmarind, shear butter and locust bean has not been determined or properly document. Therefore this research has thrown more light to work on its control measures of $C$. saratus.

\section{References}

[1] Adebayo A.A. (1999). Climate II In: Adebayo, A.A. and Tukur, A.L. (eds) 1999 Adamawa State in Maps. Pp. 23-25. Paraclete Publishers, Jimeta Yola.

[2] Adeyemi, S.A. (1968). Storage Entomology; Proceedings of Agricultural Society of Nigeria. Vol. 34

[3] Appert, J., (1987). The Storage of food Grains and Seeds. Macmillan Publishers Ltd. London, P. 146.

[4] Aribisala, O.A. (1993). Raw Material Revolution and Impact on Industrialization if. Nigeria. Mednet Ltd. Lagos Nigeria. Pp. 150.

[5] Ashle, J. (1993). Drought and Crop Adaptation ,In Dry Land Farming in Africa. (Rowland, R.J. ed). Macmillan Education Ltd. London Pp. 10.

[6] Beghmin, J. Diop, N. and Sewadah, M. (2003). The Impact of Groundnut Trade Liberalization. Tim Hill Publishing company Limited India. Pp. 241-242.

[7] Conway, J.A. (1983). Notes on the Biology and Ecology of the Groundnut seed Beetle, Caryedon serratus (Olivier). Tropical Stored Product Information 45: 11-13.

[8] Dalton, H.J. (1991). Agriculture in the Tropics and sub-Tropics. Longman Group Ltd. London Pp. 19.

[9] Fosbeg F.R. (2005). Handbook of Flora of Ceylon. Washington, D.C. Smithsnian Institute.

[10] Hooker, J.D. (1991). The Flora of British India. Viol. II. L. Reeve and company Ltd London. 25Pp.

[11] IIT A (International Institute for Tropical Agriculture) (2000). Field Crop Production Annual Report. UTA Publication, Ibadan Nigeria. P. 10.

[12] Lale, N.E.S. (1995). An Overview of the Use of Plant Products in the Management of Stored Product Coleoptera in the Tropics. Post Harvest News and Information 6:69 - 75

[13] Morga'l, N. (1973). Effects of Temperature and PH on Water Relations of Field and Storage Fungi, British Mycological Society $82: 10-12$.

[14] Nyilra, N.Z. (1988). Pest of Grain Legumes and their Control in Uganda. Academy Pres London. Pp. 22-24.

[15] Weiss, E. A. (2000) Oil Seed Crop. Blackwell Publishers, London. UK. 16.

[16] Williams, J.O. (1990). Notes on Bruchids Association with Store Products in Nigeria. Tropical Legume Bulletin 2:5-7.

[17] Yayock, J. Y. (1984). A Review of the Agronomic Principle of Groundnut Production. In. National Seminar on Groundnut Production. Institute of Agricultural Research. Ahmadu Bello University, Zaria. 45 Pp. 